\title{
Isotope geochemistry of sulfur: implications for origin and distribution of sulfur in Isparta Angle of Western Taurus Belt, SW, Turkey
}

\author{
Mustafa Kumral a,* , Zeynep Döner a \\ a Istanbul Technical University, Department of Geological Engineering, 34469, Istanbul Turkey
}

\begin{tabular}{l} 
A R T I C L E I N F O \\
\hline Article history: \\
Received 12 October 2019 \\
Received in revised form 03 November \\
2019 \\
Accepted 04 November 2019 \\
\hline Keywords: \\
Sulfur isotopes \\
Bituminous shale \\
West Taurus Belt \\
Isparta
\end{tabular}

\begin{abstract}
A B S T R A C T
The study area is located between Isparta and Burdur cities in Turkey, with an area of $350 \mathrm{~km}^{2}$. According to sulfur isotope $\left(\delta^{34} S\right)$ data of samples, the calculated $\delta^{34} \mathrm{~S}(\% \mathrm{)})$ values are between 0.0447 and 0.0449 and the variation range $\left[\Delta\left(\delta^{34} S\right)\right]$ is 7.7. These values suggest a genetic environment that suitable for a shale formation. When it was examined the volcanic rocks in the region, it has shown that the rocks were quite poor in point of sulfide ores, but it has been found Triassic bituminous shale, oil seepages in vicinity. Previous researchers asserted that the sulfur must have been originated from the volcanism. However, isotopic and geochemical analyses, detailed field surveys of volcanic rocks suggest that the sulfur has organic origin and may have occurred in a shale environment. It is thought that the sulfur may have been reached to the surface by hydrothermal water and gas in the end of the volcanism.
\end{abstract}

(C) 2019. Turkish Journal Park Academic. All rights reserved.

\section{Introduction}

Sulfur is a chemical element with the symbol $\mathrm{S}$ and atomic number 16. It is abundant, multivalent, and nonmetallic. Sulfur can be found in coal, natural gas and petroleum, meteorites, around the hot water sources, volcanic rocks, sedimentary environment, salt domes, with gypsum, anhydrite and limestone, stalactites and stalagmites, with the form of pyramidal holoedr and spherical. In nature, sulfur has three forms as solid, liquid and gas phases (Kumral, 2000). The natural state of sulfur is the mixture of stable isotopes. Approximate percent distributions of this mixture consist of \% $95.1 \mathrm{~S}^{32}, \% 0.74 \mathrm{~S}^{33}, \% 4.2 \mathrm{~S}^{34}, \% 0.016 \mathrm{~S}^{36}$. The $\mathrm{S}^{31}, \mathrm{~S}^{35}, \mathrm{~S}^{37}$ isotopes of sulfur are not natural. They are short-lived and radioactive (Tuller, 1954).

There are two types of sulfur cycles in earth's crust. The first cycle takes places between ocean waters, sedimentary rocks and evaporites. The second cycle, called the biological sulfur cycle, is the cycle between sulfates and hydrogen sulphides, in which bacteria are also involved in anaerobic environments. Sulfur deposits can be divided into groups as native sulfur deposits, plutonism-related hydrothermal deposits, volcanism-related deposits, sedimentary deposits, and saltdomed deposits (Kumral, 2000). Approximately 31\% of world sulfur production is obtained from native sulfur deposits and about 25\% from oil and natural gas refining. Approximately $54 \%$ of the production of native sulfur deposits is acquired from sulfur deposits which are formed in the form of salt dome (Aksoy et al., 1979). However, the exploitable sulfur deposits are those which contain native sulfur.

The study area that covers $350 \mathrm{~km}^{2}$ is located in Isparta Angle of Western Taurus Belt between Isparta and Burdur cities in Turkey. Both Keçiborlu (North of Isparta) and Darıdere (South of Isparta) sulfur mineralization have great interest due to their economic value. Sulfur occurred in volcanic gas (in sulfate stage as $\mathrm{H}_{2} \mathrm{~S}, \mathrm{SO}_{2}$ and $\mathrm{SO}_{3}$ ) in organic compound of coal, petroleum, bituminous shales, and geothermal water plentifully. In the study area, many petroleum indications and asphaltite layers are known for a long time. In 1992, a drilling project (up to $1860 \mathrm{~m}$ depths) was performed showing some petroleum indications in Triassic layers with many asphaltite occurrences. The main objective of this study is to determine the origin of the Isparta sulfur deposits. To achieve this main target, the detailed geologic and field relationship and isotopic analyses have been performed.

\footnotetext{
* Corresponding author.

Tel.: +902122856307

E-mail address: kumral@itu.edu.tr
} 


\section{Geological setting}

The units in the study area are divided into two sections as allochthonous and autochthonous. The units in the study area are divided into two sections as allochthonous and autochthonous. The autochthonous units begin the Upper Cretaceous limestones at the bottom. This unit is overlaid by the Upper Paleocene-Lower Eocene Kabaktepe formation consisting of clayey limestone, sandstone, claystone, limestone with detrital texture. Followed the Middle Eocene Kaylköy formation which consist of the clayey limestone, sandstone, claystone, limestone, the Lower Miocene Ağlasun formation is composed of sandstone-marl succession. Middle-Upper Miocene Gavurdüzü formation is represented by molas type of conglomerate.

During the Pliocene period by the effect of Gölcük volcanism, tephryphonolite, porphyry trachyte, augite trachyte, andesitictrachyandesitic dykes, pyroclastic materials had settled in the region. Modern lacustrine sediments and alluvium are located at the top of the autochthonous sequences. Ophiolitic rocks and Akdağ limestones that had settled in the region by two distinct activities in two different periods constitute the allochthonous units (Fig. 1). The Kasimlar formation that observed outside the study area contains the Triassic bituminous shale with some petroleum indications.

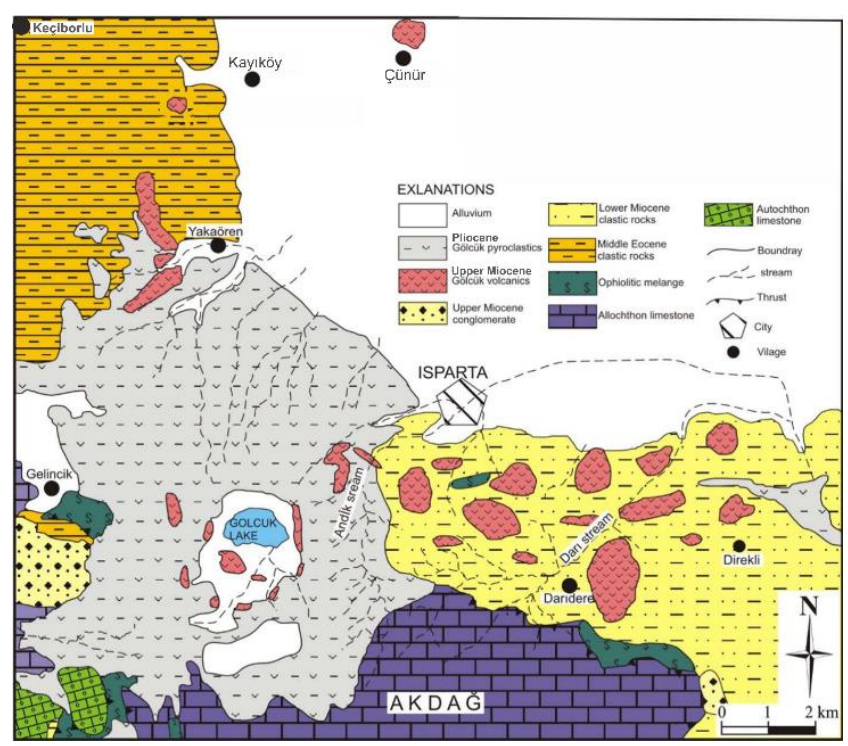

Figure 1. Geological map of the study area (Caran, 2016).

\section{Methods and approaches}

${ }^{34} \mathrm{~S}$ isotope analyses of the studied samples including native sulfur and pyrite were conducted in Geochron-Krueger Enterprises Laboratory (Massachusetts-USA). The Değirmendere (Keçiborlu, Isparta) district is quite near to the study area and exhibits similar characteristics. ${ }^{34} \mathrm{~S} /{ }^{32} \mathrm{~S}$ values were calculated by using ${ }^{34} \mathrm{~S}$ data, and tabulated in Table 1.

\section{Results and discussion}

\subsection{Sulfur isotope geochemistry}

Sulfur isotope variations on Earth can be considered relative to geologically important reservoirs. The most common reference reservoirs for sulfur isotopes in terrestrial systems are meteoritic sulfur and seawater (Fig. 2; Seal, 2006).

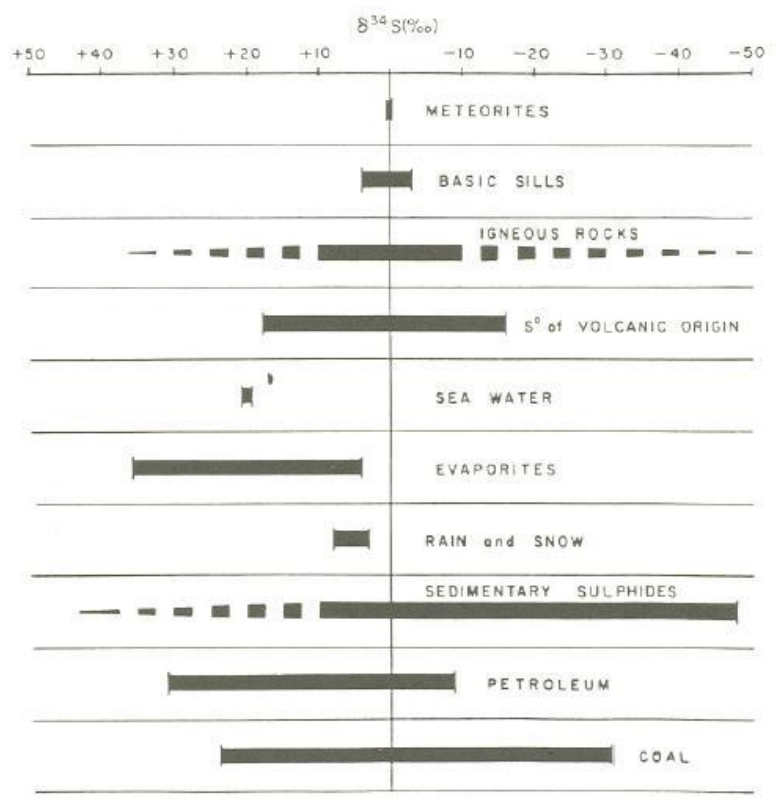

Figure 2. The ranges of $\delta^{34} S$ values found in nature for a number of different forms of sulfur (Nielsen, 1979).

Isotope ratios are usually expressed as the ratio of a minor isotope of an element to a major isotope of the element. For sulfide minerals, the principal ratio of concern is ${ }^{34} \mathrm{~S} /{ }^{32} \mathrm{~S}$. This ratio was chosen for two main reasons. Firstly, it represents the most abundant isotopes of these elements, which facilitates analysis. Secondly, isotopic fractionation is governed by the mass balance such that different isotopic ratios tend to vary systematically with one another in proportions that can be approximated by the mass differences among the isotopes (Seal, 2006).

The isotopic composition of materials is expressed in delta $(\delta)$ notation as permil, relative to the isotopic composition of the Cañon Diablo Troilite (CDT) standard which was originally defined by the isotopic composition of troilite (FeS) from the Cañon Diablo Fe meteorite as a reference. Therefore, fractionation processes cause the variations in the fifth or sixth decimals of ratios (Seal, 2006).

The $\delta$-notation for the ${ }^{34} \mathrm{~S} /{ }^{32} \mathrm{~S}$ composition of a material is defined as:

$\delta 34 S=[((34 S / 32 S)$ sample $-(34 S / 32 S)$ reference $) /(34 S /$ $32 S)$ reference $x 1000$

For CDT, the ${ }^{34} \mathrm{~S} /{ }^{32} \mathrm{~S}$ ratio is $4.50045 \times 10^{-3}$ (Ault, 1963). The ${ }^{34} \mathrm{~S} /{ }^{32} \mathrm{~S}$ ratios of samples were calculated from sulfur isotope 
data $\left(\delta^{34} \mathrm{~S}, 0 \% 00\right)$. For variation range of $\delta^{34} \mathrm{~S}$ values $\Delta\left(\delta^{34} \mathrm{~S}\right)$ notation is defined as:

$\Delta(\delta 34 S)=[\delta \max 34 S-\delta \min 34 S]$

While the variations in the sample's ${ }^{33} \mathrm{~S} /{ }^{32} \mathrm{~S}$ ratio are approximately half that of the ${ }^{34} \mathrm{~S} /{ }^{32} \mathrm{~S}$ ratio due to the relative difference in mass, the variations in the sample's ${ }^{36} \mathrm{~S} /{ }^{32} \mathrm{~S}$ ratio are approximately twice that of the ${ }^{34} \mathrm{~S} /{ }^{32} \mathrm{~S}$ ratio. This linear fractionation trend owing to physical and chemical treatments is identified as "mass-dependent fractionation" (Urey 1947; Hulston and Thode 1965a,b). In contrast, mass-independent fractionation is considered by non-linear variations in isotopic fractionation with mass. Fractionation can be considered in terms of isotopic exchange reactions, which are driven thermodynamically toward equilibrium. In a more general form, the stable isotopes' partitioning between two substances as $A$ and $B$, is quantitatively described by a fractionation factor, which is defined as:

$\alpha A-B=R A / R B$

$\mathrm{R}$ is ${ }^{34} \mathrm{~S} /{ }^{32} \mathrm{~S}$. This equation can be modified in terms of $\delta$ values using Equation (1) as:

$\alpha A-B=(1+\delta A / 1000) /(1+\delta B / 1000)=(1000+\delta A) /$

$(1000+\delta B)$

Fractionation factor which can be expressed in a variety of ways such as $\alpha, 1000 \ln \alpha$, and $\Delta$ in the literature, the $\Delta_{\mathrm{A}-\mathrm{B}}$ is defined as:

$\Delta A-B=\delta A-\delta B$

A mathematical relationship is that $1000 \ln (1.00 \mathrm{X})$ is approximately equal to $\mathrm{X}$, therefore:

$\Delta A-B \approx 1000 \ln \alpha A-B$

In addition, isotopic fractionations can be defined in terms of an enrichment factor $(\varepsilon)$, where:

$\varepsilon A-B=(\alpha A-B-1) \times 1000$

Overall, isotopic fractionation rate $(\alpha)$ of double sample of same environment is between 1.00333-1.007778. Isotopic fractionation value between two sulfurous compounds in nature reaches the value $1.086(103 \ln \alpha \sim 86)$. This value obviously indicates that considerable isotopic fractionation has occurred among sulfurous compounds, whereas isotopic fractionation value of studied sulfur sample is very low (Table $2)$. According to sulfur isotope data $\left(\delta^{34} S\right)$ of nine samples from study area, the calculated ${ }^{34} \mathrm{~S} /{ }^{32} \mathrm{~S}$ values are between 0.0447165 and 0.0449145 and the variation range of these values $\left[\Delta\left(\delta^{34} \mathrm{~S}\right)\right]$ is 7.7 (Table 1$)$. These values suggest a genetic environment that suitable for a shale formation.
Table 1. $\delta^{34} \mathrm{~S}(\% 0)$ and ${ }^{34} \mathrm{~S} /{ }^{32} \mathrm{~S}$ values of samples from study area.

\begin{tabular}{|c|c|c|c|c|c|}
\hline Sample ID & Location & Sample Type & Host Rock & $8^{34} 5(\%)$ & ${ }^{34} \mathrm{~S}{ }^{32} \mathrm{~S}$ \\
\hline KBD-1 & Değ̈rmendere (Keçiborlu) & Native sulfur & Sandstone (flysch) & -6.4 & 0.044717 \\
\hline KBD-2 & Değrmendere (Keçiborlu) & Native sulfur & Sandstone (flysch) & -6.0 & 0.044735 \\
\hline YKU-1 & Uyuzpnar (Yakaären) & Native sulfur & Sandstone (flysch) & -2.0 & 0.044915 \\
\hline YKU-2 & Uyuzpnnar (Yakaären) & Native sulfur (alteration) & Sandstone & -9.7 & 0.044568 \\
\hline DRA-1 & Dardere & Native sulfur (alteration) & Trachyandesite & -6.4 & 0.044717 \\
\hline DRA-2 & Dardere & Native sulfur (alteration) & Trachyandesite & -6.7 & 0.044703 \\
\hline DRV-1 & Dardere & Pyrite+quartz+clay (vein) & Trachyandesite & -4.3 & 0.044811 \\
\hline DRV-2 & Dardere & Pyrite+quartz+clay (vein) & Trachyandesite & -6.5 & 0.044712 \\
\hline DRV- 3 & Dardere & Pyrite+quartz+clay (vein) & Trachyandesite & -97 & 0.044568 \\
\hline
\end{tabular}

Table 2. Isotopic fractionation values of various sample pairs.

\begin{tabular}{cccccc}
\hline Sample 1 & Sample 2 & Composition & $\boldsymbol{\alpha}$ & permil & $\mathbf{1 0}^{3} \ln \boldsymbol{\alpha}$ \\
\hline YKU-1 & KBD-1 & Native sulfur & 1.00443 & 4.428 & 4 \\
DRA-1 & YKU-2 & Native sulfur (alteration) & 1.00333 & 3.332 & 3 \\
DRV-1 & DRV-3 & Pyrite+quartz+clay (vein) & 1.00545 & 5.453 & 5 \\
YKU-1 & DRV-3 & Different samples & 1.00778 & 7.775 & 8 \\
\hline
\end{tabular}

\subsection{Formation mechanism}

Previous researchers asserted that the sulfur must have been originated from the volcanism. It is thought that the sulfur may have been reached to the surface by hydrothermal water and gas in the end of the volcanism. If the sulfur had been originated from the volcanism, it must have carried some sulfide minerals by combining of chalcophile elements and these minerals must be observed in these volcanic rocks. However, isotopic and detailed field surveys of volcanic rocks suggest that the sulfur has organic origin and may have occurred in shale environment (probably derived from shale occurrences) in Western Taurus Belt.

Considering the formation mechanism in the region, in Triassic, sulfate, which entered into the semi-circulated marine basin, is reduced to $\mathrm{H}_{2} \mathrm{~S}$ by aerobic bacteria at the surface and anaerobic bacteria in the deeper zones. Under anaerobic conditions, sulfate-reducing bacteria utilize oxygen from $\mathrm{SO}_{4}{ }^{2-}$ and reduce the sulfur to $\mathrm{S}^{2-}$, that ordinarily occurs below the water-sediment interface. Bacteria extract the restricted quantity of sulfate initially present in interstitial water or provided by the slow process of diffusion. The zone of sulfate reduction is often confined inside the upper level of sediment, and the water column above the sediment doesn't contain hydrogen sulfide quitting from the sediment interface is oxidized again into sulfate by aerobic bacteria, under aerobic conditions (Dyni, 2009).

$\mathrm{H}_{2} \mathrm{~S}$ is then oxidized to $\mathrm{S}$ and $\mathrm{H}_{2} \mathrm{SO}_{4}$ by sulfur reducing bacteria. $\mathrm{H}_{2} \mathrm{SO}_{4}$ reacts with the dissolved $\mathrm{CaCO}_{3}$ present at the surface of the sea, and converted to $\mathrm{CaSO}_{4}$ and then precipitated to the bottom. This case can also be explained by a reaction between organic material and $\mathrm{CaSO}_{4}$ beside native sulfur. If the concentration of $\mathrm{CaCO}_{3}$ is not sufficient for this reaction, concentrated sulfur available in water begins to precipitate in the basin, and consequently an organic material rich in sulfur or petroleum occurs. Some reactions between sulfate and organic materials may take place during this formation as follows;

$\mathrm{CaSO} 4+2 \mathrm{C} \mathrm{CaS}+2 \mathrm{CO} 2$

$\mathrm{CaS}+\mathrm{CO} 2+\mathrm{H} 2 \mathrm{O} \quad \mathrm{CaCO} 3+\mathrm{H} 2 \mathrm{~S}$ 
$2 H 2 S+O 22 H 2 O+2 S$

$\mathrm{CaSO} 4+\mathrm{CH} 4 \quad \mathrm{CaS}+\mathrm{CO} 2+\mathrm{H} 2 \mathrm{O}$

$\mathrm{CaS}+\mathrm{CO} 2+\mathrm{H} 2 \mathrm{OCaCO} 3+\mathrm{H} 2 \mathrm{~S}$

$2 H 2 S+O 22 H 2 O+2 S$

Sulfur, formed by the above reactions, settles down at the surfaces by moving through hydrothermal solutions and sulfator phase in which the temperature ranges of $100^{\circ} \mathrm{C}$ and $150^{\circ} \mathrm{C}$ as a result of the Pliocene volcanism. This process takes place by the following reactions (Fig. 3).

$2 H 2 S+O 22 H 2 O+2 S$

$2 \mathrm{H} 2 \mathrm{~S}+3 \mathrm{O} 2 \mathrm{2SO}+2 \mathrm{H} 2 \mathrm{O}$

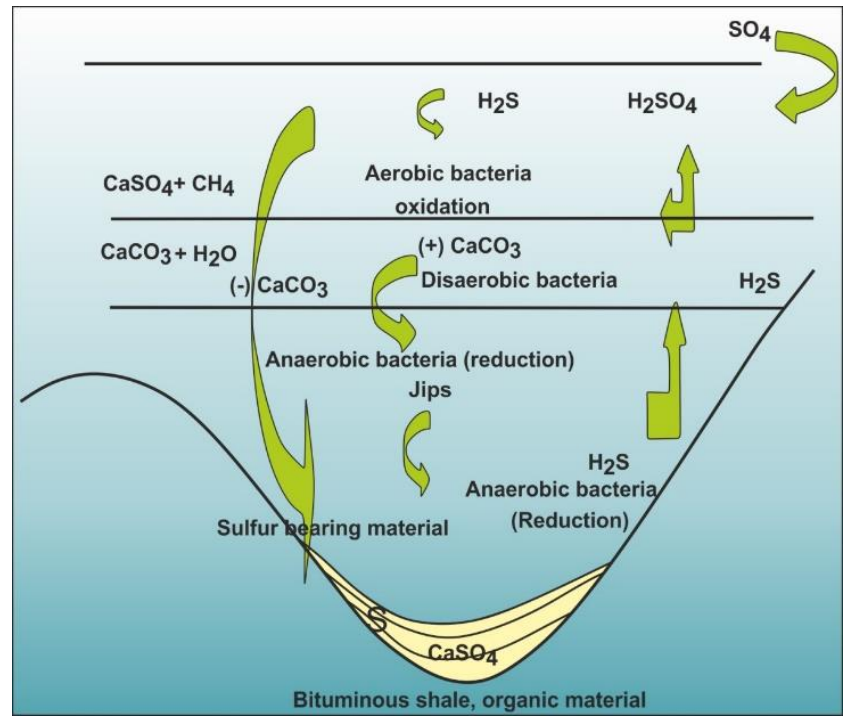

Figure 3. A schematic demonstration regarding the formation of syngenetic sulfur in a shale basin (modified from Kumral, 2000)

\section{Conclusions}

Based on the ${ }^{34} \mathrm{~S}$ isotope analyses of the studied samples including native sulfur and pyrite, the genesis of the Isparta sulfur deposits were determined, and the following conclusions were reached:

(1) A schematic demonstration regarding the formation of syngenetic sulfur in the shale basin stated that the sulfur had formed together with petroleum in Mesozoic and then transported upward by the Pliocene volcanism. Although only Jurassic and Cretaceous limestones are exposed in the study area, shales, which are the host rock of the syngenetic sulfur, can be found in deeper zones.

(2) The sulfur occurrences were originated from organic material and transported by hydrothermal solutions and also gases.

\section{References}

Aksoy, S., Alptekin, U., Şahin, K., 1979. Kimya sektör araştırması (kükürt, pirit, sülfürik asit), Türkiye Sınai Kalkınma Bankası AȘ. yayıları, No: 13, İstanbul.

Ault, W.V., 1963. Summary of sulfur isotope standards. In Biogeochemistry of Sulfur Isotopes, National Science Foundation Symposium Proceedings. Yale University, New Haven, 509-567.

Caran, Ş., 2016. Mineralogy and petrology of leucite ankaratrites with affinities to kamafugites and carbonatites from the Kaylöy area, Isparta, SW Anatolia, Turkey: Implications for the influences of carbonatite metasomatism into the parental mantle sources of silicaundersaturated potassic magmas. Lithos, 256, 13-25.

Dyni, J.R., 2009. Coal, oil shale, natural bitumen, heavy oil and peat Vol. II - Origin and resources of world oil shale deposits, Encyclopedia of Life Support Systems.

Hulston, J.R and Thode H.G., 1965a. Variations in the $\mathrm{S}^{33}$, $\mathrm{S}^{34}$, and $\mathrm{S}^{36}$ contents of meteorites and their relation to chemical and nuclear effects. Journal of Geophysical Research, 70, 3475-3484.

Hulston J.R and Thode H.G., 1965b. Cosmic-ray produced $S^{33}$ and $S^{36}$ in the metallic phase of iron meteorites. Journal of Geophysical Research 70, 4435-4442.

Kumral, M., 2000. Isparta bölgesinin jeokimyasal özellikleri ve endüstriyel hammadde potansiyeli. İstanbul Teknik Üniversitesi, Fen Bilimleri Enstitüsü, Doktora Tezi, 213 s.

Nielsen, H., 1979. Sulphur isotopes. In: Jager, E., and Hunziher, J.e. (Eds.) Lectures in isotope geology, Springer-Verlag, Berlin, 283-312.

Seal, R.R., 2006. Sulfur isotope geochemistry of sulfide minerals. Reviews in Mineralogy and Geochemistry, 61(1), 633-677.

Tuller, W.N., 1954. The sulfur data book, McGraw-Hill New York., USA

Urey, H.C., 1947. The thermodynamic properties of isotopic substances. Journal of Chemical Society, 1947, 562-581. 